\title{
Study of maternal, fetal and neonatal outcomes in patients with gestational diabetes mellitus in a tertiary care hospital
}

\author{
Deepali S. Jadhav*, Uma N. Wankhede
}

Department of Obstetrics and Gynecology, BJGMC and SGH Pune, Maharashtra, India

Received: 28 April 2017

Accepted: 22 May 2017

\section{*Correspondence:}

Dr. Deepali S. Jadhav,

E-mail: deepjadhav1988@gmail.com

Copyright: (C) the author(s), publisher and licensee Medip Academy. This is an open-access article distributed under the terms of the Creative Commons Attribution Non-Commercial License, which permits unrestricted non-commercial use, distribution, and reproduction in any medium, provided the original work is properly cited.

\begin{abstract}
Background: GDM is defined as carbohydrate intolerance of variable severity with onset or first recognition during pregnancy. Women with gestational diabetes are characterized by a relatively diminished insulin secretion and pregnancy induced insulin resistance primarily present in the skeletal muscle tissue. Normal pregnancy is a diabetogenic state characterized by exaggerated rate and amount of insulin release, associated with decreased sensitivity to insulin at cellular levels. The objective of the study was to study the maternal, the fetal and the neonatal outcomes of treated patients of GDM in present study.

Methods: It was a hospital based clinical study. 1000 patients were enrolled between 24-28 weeks of gestation and DIPSI test was performed. Diagnosis of GDM was done using DIPSI criteria. 80 patients were diagnosed with GDM and followed till delivery to study the maternal, fetal and neonatal outcome.

Results: Elderly patients, patients with previous history of GDM, patients with family history of diabetes, patients with high BMI and patients with polyhydramnios are at high risk for GDM.

Conclusions: Hypertensive disorders and preterm birth are known to be higher with GDM are similar to the nonGDM group suggesting that early diagnosis and prompt treatment and maintaining strict glycemic control by patient may be beneficial. GDM can be managed well on MNT and lifestyle modifications, only few patients required insulin therapy. In spite of appropriate glycemic control, the incidence of macrosomia found to be high in GDM group. Sudden unexplained stillbirth can occur in spite of strict glycemic control. Neonatal complications have occurred despite well glycemic control.
\end{abstract}

Keywords: DIPSI, GDM, MNT, Macrosomia, Stillbirth

\section{INTRODUCTION}

Diabetes mellitus is a group of metabolic disorders characterized by hyperglycemia resulting from defects in insulin secretion, insulin action or both. ${ }^{1}$ It is defined as carbohydrate intolerance of variable severity with an onset or first recognition during pregnancy. ${ }^{2}$ Women with gestational diabetes are characterized by a relatively diminished insulin secretion and pregnancy induced insulin resistance primarily present in the skeletal muscle tissue. Normal pregnancy is a diabetogenic state characterized by exaggerated rate and amount of insulin release, associated with decreased sensitivity to insulin at cellular levels. Many of the changes are results of the progressive rise in the levels of estrogen, progesterone, human placental lactogen, cortisol and prolactin as pregnancy advances. Many of these hormones are insulin antagonists, causing insulin resistance in the mother and cause abnormal glucose tolerance in some women rendering them to develop gestational diabetes. ${ }^{3}$ During early pregnancy, glucose crosses the placenta to the fetus by facilitated diffusion resulting in the decrease in fasting 
blood glucose to $50-65 \mathrm{mg} \%$. As pregnancy progresses 3 factors are responsible for causing post prandial hyperglycemia: insulin antagonists such as estrogen, progesterone and human placental lactogen. There is 3fold rise in serum cortisol and human placenta contains enzymes (eg. insulinase) that increase the degradations by potentiating the secretion of insulin, but in GDM the pancrease fail to respond adequately. ${ }^{4}$ GDM is associated with increased fetomaternal morbidity as well as long term complications in mother and babies. American college of obstetricians and gynecologists (ACOG) on contrary advocates selective screening for patients with high risk factors such as history of previous GDM, strong family history of diabetes, member of an ethnic group with high prevalence of GDM, maternal age more than 25 years, obesity, persistent glycosuria, macrosomia (birth weight $>4 \mathrm{gm}$,)polycystic ovarian syndrome, spontaneous abortions and unexplained still births. ${ }^{5}$ Maternal complications are increased incidence of asymptomatic bacteriuria, urinary tract infections, increased incidence of pre ecclamsia, $10 \%$ risk of polyhydramnios which may increase the incidence of preterm labour, placental abruption and postpartum hemorrhage. Risk of developing diabetes mellitus and the complications in fetus are macrosomia, which will increase risk of operative delivery and shoulder dystocia, increase incidence of hypoglycemia, hypocalcemia, congenital malformations, polycythemia, hyperbilirubinemia, respiratory distress syndrome, and long term complications are obesity, development of type 2 diabetes mellitus during childhood, impaired motor functions and higher rates of in attention and hyper activity. ${ }^{6}$ Several studies have shown that 50\% GDM developed diabetes mellitus within 10-20 years of index pregnancy. Furthermore, there were reported increased incidence of hypertension, hyperlipedimia, proteinuria, abnormal ECG and higher morbidity and mortality.

The incidence of juvenile diabetes mellitus in offspring is 20 times more than in the controlled population. Attempts to detect unrecognized diabetes in pregnancy should be practiced in antenatal clinics which are justified by the increased risk of maternal, perinatal and neonatal morbidity mortality among women with abnormal OGTT in pregnancy.

\section{METHODS}

It was a hospital based study. 1000 pregnant women in second trimester between 24-28 weeks of gestational age attending antenatal clinic of tertiary care center in a time period of one year (September 2015 to December 2016) were enrolled in this study after providing informed consent. Diagnosis of GDM was done using DIPSI criteria. A detailed assessment of patient was performed including history (any family history of diabetes, history of previous pregnancies and socioeconomic status etc.), general examination and obstetric examination. Routine investigations during antenatal visits were done. Informed consent to participation was taken during initial assessment. A standard proforma was used to record the data of tests performed, detailed clinical assessment of patients, including history and examination findings, investigations including the test results.

Diabetes in Pregnancy Study Group India (DIPSI) diagnostic criterion of 2 -h plasma glucose $\geq 7.8 \mathrm{mmol} / \mathrm{L}$ with $75 \mathrm{gm}$ oral glucose load is a modified version of WHO criterion, in that the WHO procedure requires women to be in the fasting state, whereas DIPSI procedure was performed in the fasting/ non-fasting state irrespective of last meal timing. Diagnosis of GDM according to DIPSI criteria is as follows. ${ }^{7}$

\section{Inclusion criteria}

- All consenting pregnant women in second trimester between 24-28 weeks

- Pregnant women of any parity

- $\quad$ Singleton pregnancy.

\section{Exclusion criteria}

- Pre-gestational diabetes

- Chronic renal/ cardiac/ hepatic/ respiratory diseases

- Taking drugs that alter glucose metabolism

- Women who refuse to participate.

Table 1: DIPSI criteria.

\begin{tabular}{|ll|}
\hline Interpretation of OGTT & $\begin{array}{l}\text { 2-hour venous blood } \\
\text { sugar }(\mathbf{m g} / \mathrm{dI})\end{array}$ \\
\hline Normal & $<140$ \\
\hline Gestational diabetes mellitus & $140-199$ \\
\hline Overt diabetes & $\geq 200$ \\
\hline
\end{tabular}

\section{RESULTS}

Out of the 1000 women screened 80 women were diagnosed as GDM using DIPSI criteria. Maternal, fetal and neonatal outcomes compared in women with GDM and those without GDM.

Table 2: Co-relation of advanced maternal age with GDM.

\begin{tabular}{|c|c|c|c|c|}
\hline & & \multicolumn{2}{|l|}{ GDM } & \multirow{2}{*}{ Total } \\
\hline & & Yes & No & \\
\hline \multirow{2}{*}{$\begin{array}{l}\text { Elderly } \\
\text { gravida } \\
\text { ( } \geq 35 \text { years) }\end{array}$} & Yes & $\begin{array}{l}7 \\
(26.92 \%)\end{array}$ & $\begin{array}{l}19 \\
(73.08 \%)\end{array}$ & $\begin{array}{l}26 \\
(2.6 \%)\end{array}$ \\
\hline & No & $\begin{array}{l}73 \\
(7.49 \%)\end{array}$ & $\begin{array}{l}901 \\
(92.51 \%)\end{array}$ & $\begin{array}{l}974 \\
(97.4 \%)\end{array}$ \\
\hline Total & & $\begin{array}{l}80 \\
(8 \%)\end{array}$ & $\begin{array}{l}920 \\
(92 \%)\end{array}$ & $\begin{array}{l}1000 \\
(100 \%)\end{array}$ \\
\hline
\end{tabular}

From Table 2 there were total 26 elderly ( $\geq 35$ years) pregnant woman of which $7(26.92 \%)$ were diagnosed with gestational diabetes mellitus and 19 (73.08\%) were having non-GDM. For Table 2 Pearson's chi-square value is 12.99 , df is 1 and $P$ value is 0.0003 , which is 
statistically significant and implies positive co-relation of advanced maternal age with gestational diabetes mellitus.

Table 3: Incidence of GDM in different BMI groups at first registration.

\begin{tabular}{|llll|}
\hline BMI $(\mathrm{kg} / \mathrm{m} 2)$ & GDM & Total \\
\hline High $(>30)$ & 9 & 5 & 14 \\
& $(64.29 \%)$ & $(35.71 \%)$ & $(1.4 \%)$ \\
\hline Low $(<19)$ & 1 & 128 & 129 \\
& $(0.78 \%)$ & $(99.22 \%)$ & $(12.9 \%)$ \\
Normal & 70 & 787 & 857 \\
$(19-29.99)$ & $(8.17 \%)$ & $(91.83 \%)$ & $(85.7 \%)$ \\
\hline Total & 80 & 920 & 1000 \\
& $(8 \%)$ & $(92 \%)$ & $(100 \%)$ \\
\hline
\end{tabular}

From Table 3, incidence of gestational diabetes mellitus in high body mass index group (>30) was $64.29 \%$ whereas in normal body mass index group (19-29.99) is $8.17 \%$. In low Body mass index $(<19)$ incidence of gestational diabetes mellitus was $0.78 \%$. For Table 3 chisquare value is 69.44 , df is 2 and $\mathrm{P}$ value is $<0.0001$. Which signifies positive co-relation of high body mass index with incidence of gestational diabetes mellitus.

Table 4: Co-relation of gravidity with GDM.

\begin{tabular}{|c|c|c|c|c|}
\hline & \multicolumn{3}{|c|}{ GDM } & \multirow{2}{*}{ Total } \\
\hline & & Yes & No & \\
\hline \multirow{2}{*}{ Gravidity } & Primigravida & $\begin{array}{l}6 \\
(7.5 \%)\end{array}$ & $\begin{array}{l}174 \\
(18.91 \%)\end{array}$ & $\begin{array}{l}180 \\
(18 \%)\end{array}$ \\
\hline & $\begin{array}{l}\text { G2 and } \\
\text { above }\end{array}$ & $\begin{array}{l}74 \\
(92.5 \%)\end{array}$ & $\begin{array}{l}746 \\
(81.09 \%)\end{array}$ & $\begin{array}{l}820 \\
(82 \%)\end{array}$ \\
\hline Total & & $\begin{array}{l}80 \\
(8 \%)\end{array}$ & $\begin{array}{l}920 \\
(92 \%)\end{array}$ & $\begin{array}{l}1000 \\
(100 \%)\end{array}$ \\
\hline
\end{tabular}

From Table 4 the incidence of GDM in primigravida was $6(7.5 \%)$ and in multigravida it was $74(92.5 \%)$. For

Table 4 Pearson's chi-square value is 5.74, df is 1 and $\mathrm{P}$ value is 0.016 , which implies positive co-relation between multigravida and GDM.

Table 5: Co-relation between previous history of GDM and GDM.

\begin{tabular}{|c|c|c|c|c|}
\hline & & GDM & & Tatol \\
\hline & & Yes & No & Iotal \\
\hline Previous & Yes & $\begin{array}{l}18 \\
(22.5 \%)\end{array}$ & $\begin{array}{l}9 \\
(0.98 \%)\end{array}$ & $\begin{array}{l}27 \\
(2.7 \%)\end{array}$ \\
\hline $\begin{array}{l}\text { history of } \\
\text { GDM }\end{array}$ & No & $\begin{array}{l}62 \\
(77.5 \%)\end{array}$ & $\begin{array}{l}911 \\
(99.02 \%)\end{array}$ & $\begin{array}{l}973 \\
(97.3 \%)\end{array}$ \\
\hline Total & & $\begin{array}{l}80 \\
(8 \%)\end{array}$ & $\begin{array}{l}920 \\
(92 \%)\end{array}$ & $\begin{array}{l}1000 \\
(100 \%)\end{array}$ \\
\hline
\end{tabular}

Table 5 shows that there were total 27 patients with previous history of GDM of which 18 (22.5\%) developed
GDM in this pregnancy and only $9(0.98 \%)$ were non GDM.

Out of 973 patients with no previous history of GDM only $62(77.50 \%)$ developed GDM and 911 (99.02\%) were non GDM. For Table 5 Pearson's chi-square value is 121.7 , df is 1 and $P$ value is $<0.0001$. Which signifies positive co-relation between previous history of GDM and GDM.

Table 6: Co-relation between family history of diabetes and GDM.

\begin{tabular}{|c|c|c|c|c|}
\hline & & \multicolumn{2}{|l|}{ GDM } & \multirow{2}{*}{ Total } \\
\hline & & Yes & No & \\
\hline \multirow{2}{*}{$\begin{array}{l}\text { Family } \\
\text { history of } \\
\text { diabetes }\end{array}$} & Yes & $\begin{array}{l}34 \\
(42.5 \%)\end{array}$ & $\begin{array}{l}78 \\
(8.48 \%)\end{array}$ & $\begin{array}{l}112 \\
(11.2 \%)\end{array}$ \\
\hline & No & $\begin{array}{l}46 \\
(57.5 \%)\end{array}$ & $\begin{array}{l}842 \\
(91.52 \%)\end{array}$ & $\begin{array}{l}888 \\
(88.8 \%)\end{array}$ \\
\hline Total & & $\begin{array}{l}80 \\
(8 \%)\end{array}$ & $\begin{array}{l}920 \\
(92 \%)\end{array}$ & $\begin{array}{l}1000 \\
(100 \%)\end{array}$ \\
\hline
\end{tabular}

Table 6 shows that in our study out of 80 patients with GDM, 34 (42.5\%) had family history of diabetes in first degree relative while $46(57.5 \%)$ had no family history of diabetes. Also, out of 920 patients with non GDM only $78(8.48 \%)$ had family history of diabetes and 842 $(91.52 \%)$ had no family history of diabetes mellitus.

For Table 6 Pearson's chi-square value is 82.27 , df is 1 and $\mathrm{P}$ value is $<0.0001$. Which shows strong association between family history of diabetes and GDM.

Table 7: Distribution of obstetric and medical risk factors.

\begin{tabular}{|lll|}
\hline $\begin{array}{l}\text { Obstetric and medical risk } \\
\text { factors }\end{array}$ & Number & $\%$ \\
\hline Previous LSCS & 117 & 11.70 \\
\hline Pre-eclampsia & 109 & 10.90 \\
\hline Anaemia & 109 & 10.90 \\
\hline GDM & 80 & 8.00 \\
\hline Elderly gravida & 26 & 2.60 \\
\hline Hypothyroidism & 20 & 2.00 \\
\hline PROM & 12 & 1.20 \\
\hline Polyhydramnios & 22 & 2.20 \\
\hline Oligohydramnios & 3 & 0.30 \\
\hline Abruption & 1 & 0.10 \\
\hline
\end{tabular}

In study sample of 1000 participants obstetric and medical risk factors like previous LSCS, pre-eclampsia, anaemia and gestational diabetes mellitus were important factors having occurrence rate of $11.70 \%, 10.90 \%$, $10.90 \%$ and $8.00 \%$. Whereas elderly gravida, hypothyroidism, PROM, polyhydramnios, oligohydramnios and abruption factors constituted about $2.60 \%, 2.00 \%, 1.20 \%, 2.20 \%, 0.30 \%$ and $0.10 \%$ respectively in sample. 
Table 8: Co-relation of pre-eclampsia with gestational diabetes mellitus.

\begin{tabular}{|lllll|}
\hline & & GDM & & \\
& & Yes & No & Total \\
\hline \multirow{3}{*}{$\begin{array}{l}\text { Pre- } \\
\text { eclampsia }\end{array}$} & Yes & 9 & 100 & 109 \\
& & $(11.25 \%)$ & $(10.87 \%)$ & $(10.9 \%)$ \\
\cline { 3 - 5 } & No & 71 & 820 & 891 \\
\multirow{2}{*}{ Total } & & $(88.75 \%$ & $(89.13 \%)$ & $(89.1 \%)$ \\
& & $(80)$ & 920 & 1000 \\
& & & $(92 \%)$ & $(100 \%)$ \\
\hline
\end{tabular}

From Table 8, incidence of pre-eclampsia was almost same in gestational diabetes mellitus $(11.25 \%)$ and nongestational diabetes mellitus group (10.87\%). For Table 8 Pearson's chi-square value is 0.01 , df is 1 and $P$ value is 0.92 . Which is statistically non-significant and implies there is no co-relation between gestational diabetes mellitus and occurrence of pre-eclampsia.

Table 9: Co-relation of GDM and polyhydramnios.

\begin{tabular}{|c|c|c|c|}
\hline \multirow{2}{*}{$\begin{array}{l}\text { Amniotic fluid } \\
\text { index }\end{array}$} & \multicolumn{2}{|l|}{ GDM } & \multirow{2}{*}{ Total } \\
\hline & Yes & No & \\
\hline $\begin{array}{l}\text { Polyhydramnios } \\
(>20 \mathrm{~cm})\end{array}$ & $\begin{array}{l}6 \\
(7.5 \%)\end{array}$ & $\begin{array}{l}16 \\
(1.74 \%)\end{array}$ & $\begin{array}{l}22 \\
(2.2 \%)\end{array}$ \\
\hline Normal $(5-19.9 \mathrm{~cm})$ & $\begin{array}{l}74 \\
(92.5 \%)\end{array}$ & $\begin{array}{l}901 \\
(97.94 \%)\end{array}$ & $\begin{array}{l}975 \\
(97.5 \%)\end{array}$ \\
\hline $\begin{array}{l}\text { Oligohydramnios } \\
(<5 \mathrm{~cm})\end{array}$ & 0 & $\begin{array}{l}3 \\
(0.33 \%)\end{array}$ & $\begin{array}{l}3 \\
(0.3 \%)\end{array}$ \\
\hline Total & $\begin{array}{l}80 \\
(8 \%)\end{array}$ & $\begin{array}{l}920 \\
(82 \%)\end{array}$ & $\begin{array}{l}1000 \\
(100 \%)\end{array}$ \\
\hline
\end{tabular}

For study purpose, we have defined polyhydramnios as amniotic fluid index (AFI) more than $20 \mathrm{~cm}$ and oligohydramnios as amniotic fluid index less than $5 \mathrm{~cm}$. From Table 9, in patients with gestational diabetes mellitus polyhydramnios was found in $6(7.5 \%)$ cases and normal AFI in $74(92.5 \%)$ cases. Whereas in nongestational diabetes mellitus group polyhydramnios was found in $16(1.74 \%)$ cases, oligohydramnios in $3(0.33 \%)$ cases and normal AFI in 901 (97.94\%) cases. For Table 9 chi-square value is 11.59 , df is 2 and $\mathrm{P}$ value is 0.003 which suggests association of polyhydramnios with gestational diabetes mellitus.

Table 10: Comparison of fetal anomaly in GDM and non-GDM group.

\begin{tabular}{|llll|}
\hline $\begin{array}{l}\text { Fetal } \\
\text { anomaly }\end{array}$ & Yes & No & Total \\
\hline \multirow{2}{*}{ Yes } & 3 & 25 & 28 \\
& $(3.75 \%)$ & $(2.72 \%)$ & $(2.8 \%)$ \\
\multirow{2}{*}{ No } & 77 & 895 & 972 \\
& $(96.25 \%)$ & $(97.28 \%)$ & $(97.2 \%)$ \\
\hline \multirow{2}{*}{ Total } & 80 & 920 & 1000 \\
& $(8 \%)$ & $(92 \%)$ & $(100 \%)$ \\
\hline
\end{tabular}

From Table 10, incidence of congenital anomalies was almost same in gestational diabetes mellitus (3.75\%) and non-gestational diabetes mellitus group (2.72\%). For Table 10 Pearson's chi-square value is 0.29 , df is 1 and $\mathrm{P}$ value is 0.59 . Which is statistically non-significant and implies there is no co-relation between gestational diabetes mellitus and congenital anomalies.

From Table 11, incidence of macrosomia in gestational diabetes mellitus was $42.50 \%$ whereas it was quite low for non-gestational diabetes mellitus i.e. $8.70 \%$. Whereas normal and low weight babies were relatively higher in non-gestational diabetes mellitus cases $(80 \%$ and $11.30 \%$ respectively) than in case of gestational diabetes mellitus cases $(52.50 \%$ and $5 \%$ respectively).

Table 11: Co-relation of birth weight in GDM and non-GDM.

\begin{tabular}{|llll|}
\hline Birth Weight & GDM & & Total \\
\hline Macrosomia & 34 & 80 & 114 \\
$(\geq 3.5 \mathrm{~kg})$ & $(42.5 \%)$ & $(8.70 \%)$ & $(11.4 \%)$ \\
\hline Normal & 42 & 736 & 778 \\
$(2.4-3.5 \mathrm{~kg})$ & $(52.5 \%)$ & $(80.0 \%)$ & $(77.8 \%)$ \\
\hline Low & 4 & 104 & 108 \\
$(\leq 2.4 \mathrm{~kg})$ & $(5.0 \%)$ & $(11.30 \%)$ & $(10.8 \%)$ \\
\hline Total & 80 & 920 & 1000 \\
& $(8 \%)$ & $(92 \%)$ & $(100 \%)$ \\
\hline
\end{tabular}

For Table 11 chi-square value is 83.64 , df is 2 and $\mathrm{P}$ value is $<0.0001$ which suggests there is strong corelation between macrosomia and gestational diabetes mellitus.

Table 12: Treatment given in GDM.

\begin{tabular}{|c|c|c|c|}
\hline $\begin{array}{l}\text { Mode of } \\
\text { treatment }\end{array}$ & $\begin{array}{l}\text { MNT+ } \\
\text { lifestyle } \\
\text { modification } \\
+ \text { SMBG }\end{array}$ & $\begin{array}{l}\text { MNT + lifestyle } \\
\text { modification } \\
\text { +SMBG } \\
\text { +insulin }\end{array}$ & Total \\
\hline $\begin{array}{l}\text { No. of } \\
\text { patients }\end{array}$ & 67 & - & 80 \\
\hline$\%$ & 83.75 & 16.25 & 100 \\
\hline
\end{tabular}

Out of 80 patients $67(83.75 \%)$ were controlled on MNT and lifestyle modification and 13 (16.25\%) patients additionally required insulin therapy.

Table 13: Comparison of gestational age at delivery in GDM and non-GDM.

\begin{tabular}{|llll|}
\hline $\begin{array}{l}\text { Gestational age } \\
\text { at delivery }\end{array}$ & GDM & No & Total \\
\hline \multirow{2}{*}{ Term } & 67 & 758 & 825 \\
& $(83.75 \%)$ & $(82.39 \%)$ & $(82.5 \%)$ \\
\hline \multirow{2}{*}{ Preterm } & 13 & 162 & 175 \\
& $(16.25 \%)$ & $(17.61 \%)$ & $(17.5 \%)$ \\
\hline Total & 80 & 920 & 1000 \\
& $(8 \%)$ & $(92 \%)$ & $(100 \%)$ \\
\hline
\end{tabular}


From Table 13, incidence preterm delivery was almost same in gestational diabetes mellitus $(16.25 \%)$ and nongestational diabetes mellitus group $(17.61 \%)$. The incidence of term delivery was $(83.75 \%)$ in GDM and $(82.39 \%)$ in non GDM group.

For Table 13 Pearson's chi-square value is 0.02 , df is 1 and $\mathrm{P}$ value is 0.8875 . Which is statistically nonsignificant and implies there no is co-relation between gestational diabetes mellitus and gestational age at delivery. From Table 14, incidences of caesarean, instrumental and normal deliveries in patients with gestational diabetes mellitus cases were $23.75 \%, 3.75 \%$ and $72.50 \%$ respectively whereas in non-gestational diabetes mellitus cases it stood for $26.85 \%, 2.61 \%$ and $70.54 \%$ respectively, which were approximately equal in both GDM and non-GDM cases.

Table 14: Co-relation of type of delivery with GDM and non-GDM.

\begin{tabular}{|llll|}
\hline $\begin{array}{l}\text { Type of } \\
\text { delivery }\end{array}$ & Yes & No & Total \\
\hline Caesarean & 19 & 247 & 266 \\
& $(23.75 \%)$ & $(26.85 \%)$ & $(26.6 \%)$ \\
\hline \multirow{2}{*}{ Instrumental } & 3 & 24 & 27 \\
& $(3.75 \%)$ & $(2.61 \%)$ & $(2.7 \%)$ \\
\hline \multirow{2}{*}{ Normal } & 58 & 649 & 707 \\
& $(72.5 \%)$ & $(70.54 \%)$ & $(70.7 \%)$ \\
\hline \multirow{2}{*}{ Total } & 80 & 920 & 1000 \\
& $(8 \%)$ & $(92 \%)$ & $(100 \%)$ \\
\hline
\end{tabular}

For Table 14 chi-square value is 0.66 , df is 2 and $\mathrm{P}$ value is 0.7189 which suggests there is no co-relation of type of delivery with gestational diabetes mellitus.

Neonatal complications like hyperbilirubinemia (12.5\%), hypoglycemia $(10 \%)$, RDS $(5 \%)$, still birth $(2.5 \%)$ and sepsis $(3.75 \%)$ (table 22) in gestational diabetes mellitus were collectively $33.75 \%$ whereas they stood at $4.78 \%$ (Table 15) for non-gestational diabetes mellitus group.

Table 15: Neonatal complications in GDM and nonGDM.

\begin{tabular}{|l|lll|}
\hline $\begin{array}{l}\text { Neonatal } \\
\text { complications }\end{array}$ & Yes & No & Total \\
\hline \multirow{2}{*}{ Yes } & 27 & 44 & 71 \\
& $(33.75 \%)$ & $(4.78 \%)$ & $(7.1 \%)$ \\
\hline \multirow{2}{*}{ No } & 53 & 876 & 929 \\
& $(66.25 \%)$ & $(95.22 \%)$ & $(92.9 \%)$ \\
\hline \multirow{2}{*}{ Total } & 80 & 920 & 1000 \\
& $(8 \%)$ & $(92 \%)$ & $(100 \%)$ \\
\hline
\end{tabular}

For Table 16 Pearson's chi-square value is 89.29 , df is 1 and $\mathrm{P}$ value is $<0.0001$ which implies very strong corelation of gestational diabetes mellitus with incidence of neonatal complications.
Table 16: Incidence of neonatal complications in GDM cases.

\begin{tabular}{|lll|}
\hline Neonatal complications & Number & $\%$ \\
\hline Hyperbilirubinemia & 10 & 12.5 \\
\hline Hypoglycemia & 8 & 10 \\
\hline RDS & 4 & 5 \\
\hline Sepsis & 3 & 3.75 \\
\hline Still Birth & 2 & 2.5 \\
\hline Total & 27 & 33.75 \\
\hline
\end{tabular}

\section{DISCUSSION}

\section{Risk factors for GDM}

Compared with women of normal OGTT, women with GDM were older. The mean age in GDM group was $26.625 \pm 4.309$ years while in non-GDM group it was $25.269 \pm 3.505$ years. Similar study from south India showed age more than 25 years as a risk factor for GDM. $^{8}$

Several studies revealed that obesity is significant risk factor for GDM. Obesity or overweight at the start of pregnancy predisposes to GDM. In present study, we had $64.29 \%$ obese $\left(\mathrm{BMI}>30 \mathrm{~kg} / \mathrm{m}^{2}\right)$ cases were having GDM, which was $67 \%\left(\mathrm{BMI}>25 \mathrm{~kg} / \mathrm{m}^{2}\right)$ in study done by Kalra $\mathrm{P}$ et al. (Jodhpur, Rajasthan) and was $27.5 \%$ $\left(\mathrm{BMI}>25 \mathrm{~kg} / \mathrm{m}^{2}\right)$ in study done by Wahi P et al. (Jammu and Kashmir). The positive correlation of obesity with GDM was also shown by studies like Nilofer AR et al as $88.89 \%$, by Das et al as $25 \% .^{9,10}$

In present study $92.5 \%$ cases of GDM were multigravida (gravida 2 and above), whereas in study done by Rajput M. et al it was $18.2 \%$, while in study done by Seshiah et al it was $25.8 \%$, these both studies considered multigravida as gravida 4 and above. ${ }^{11,12}$ It suggests significant correlation between multigravidity and GDM.

In current study, there were $22.5 \%$ cases of GDM having previous history of GDM, while in study done by Seshiah et al about $50 \%$ patients were having previous history of GDM. ${ }^{13}$ In this study, there were $42.5 \%$ cases of GDM having family history of diabetes in first degree relatives, while in study done by Bhat M. et al it was $37.3 \% .{ }^{14}$ In study done by Wahi $\mathrm{P}$ et al it was $24.19 \%$, whereas in study done by Seshiah et al it was $32.3 \%$. In study done by Sivakumar V et al it was $64.86 \%$ while in study done by Rajput M. et al it was $18.14 \% .^{15,8,16,11}$ Thus, family history of diabetes is significant risk factor associated with development of GDM.

\section{Incidence of obstetric complications in GDM cases}

In this study hypertensive disorders in pregnancy like pre-eclampsia was found in $9(11.25 \%)$ cases, PROM in $1(1.25 \%)$ case, preterm labour in $13(16.25 \%)$ cases and LSCS was done in $19(23.75 \%)$ cases. In present study, all the obstetric complications associated with GDM were 
on lower side. This may be due to early diagnosis and prompt treatment of GDM with patient education, medical nutrition therapy, lifestyle modification and appropriate glycemic control by insulin therapy wherever necessary. In Kalra P et al study, the rate of hypertensive disorders of pregnancy, antepartum haemorrhage and LSCS were high. In present study, we studied type of delivery in GDM patients. Amongst 80 patients with GDM, $19(23.75 \%)$ patients were delivered by caesarean section, $58(72.5 \%)$ patients. were delivered vaginally and $3(3.75 \%)$ patients had instrumental delivery. In present study rate of LSCS was $23.75 \%$ and the most common indication of LSCS was meconium stained liquor $(31.58 \%)$; non-progress of labour (15.79\%); CPD, macrosomia, previous LSCS (10.53\% each); breech etc. In present study number of term deliveries in GDM patients were $67(83.75 \%)$, while $13(16.25 \%)$ GDM patients had preterm delivery.

Table 17: Comparison of incidences of obstetric complications in GDM cases in various studies in India.

\begin{tabular}{|llllll|}
\hline Study & $\begin{array}{l}\text { Hypertensive disorders in } \\
\text { pregnancy }\end{array}$ & $\begin{array}{l}\text { Antepartum } \\
\text { haemorrhage }\end{array}$ & PROM & Preterm & LSCS \\
\hline Present study & $9(11.25 \%)$ & - & $1(1.25 \%)$ & $13(16.25 \%)$ & $19(23.75 \%)$ \\
\hline Kalra P et al. & $9(27 \%)$ & $7(21 \%)$ & $6(18.1 \%)$ & - & $26(76 \%)$ \\
\hline Wahi P et al. & $4(6.4 \%)$ & $2(2.7 \%)$ & - & $13(20.1 \%)$ & $14(22.5 \%)$ \\
\hline
\end{tabular}

\section{Fetal outcomes in various studies}

In our study when we compared the birth weight of babies in patients with GDM, $34(42.5 \%)$ patients had macrosomic baby $(\geq 3.5 \mathrm{~kg}), 42(52.5 \%)$ patients had normal weight babies (2.4-3.5 kg), whereas $4(5 \%)$ patients had low birth weight babies $(\leq 2.4 \mathrm{~kg})$ and all these 4 babies were preterm $(<37$ weeks). None of the babies had extremely low birth weight $(<1 \mathrm{~kg})$.
In present study, there were $2(2.5 \%)$ full term unexplained intrauterine fetal demise (stillbirth). Both patients were on medical nutritional therapy and advised lifestyle modifications. Both patients had good glycemic control. Fetal demise may be due to extramedullary hematopoiesis due to chronic hypoxia and electrolyte imbalance. Whereas in study done by Priyanka Kalra, et al. still birth was $3(9.09 \%)$ and in study done by Wahi P, et al stillbirth was $3(4.84 \%)$ cases.

Table 18: Comparison of fetal outcomes in various studies in India.

\begin{tabular}{|lllllll} 
Study & Still birth & Macro-somia & Hypoglycemia & Hyperbilirubinemia & $\begin{array}{l}\text { Shoulder } \\
\text { Dystocia }\end{array}$ & $\begin{array}{l}\text { NICU } \\
\text { admission }\end{array}$ \\
\hline Present study & $2(2.5 \%)$ & $34(42.5 \%)$ & $8(10 \%)$ & $10(12.5 \%)$ & - & $17(21.25 \%)$ \\
\hline Kalra P et al. & $3(9.09 \%)$ & $6(18 \%)$ & $3(9.05 \%)$ & $6(10.12 \%)$ & $7(10 \%)$ & $9(27.2 \%)$ \\
Wahi P et al. & $3(4.84 \%)$ & $7(11 \%)$ & - & - & $1(3 \%)$ & - \\
\hline
\end{tabular}

Out of 143 babies born 17 (21.25\%) babies were admitted in NICU. Most common reason for Macrosomic babies were high $34(42.5 \%)$ in present study, whereas $6(18 \%)$ in study done by Priyanka Kalra, et al. and $7(11 \%)$ in study done by Wahi P., et al There were $8(10 \%)$ babies of neonatal hypoglycemia in present study, while there were $3(9.05 \%)$ babies in study done by Priyanka Kalra, et al.

There were $10 \quad(12.5 \%)$ babies of neonatal hyperbilirubinemia in our study, while there were 6 $(10.12 \%)$ babies in study done by Priyanka Kalra, et al. There was no case of shoulder dystocia in our present study as was seen in $7(10 \%)$ cases in study done by Kalra $\mathrm{P}$ et al. and $1(3 \%)$ case in study done by Wahi $\mathrm{P}$, et al.

\section{CONCLUSION}

Study found that elderly patients, patients with previous history of GDM, patients with family history of diabetes, patients with high BMI and patients with polyhydramnios are at high risk for GDM. In study, obstetric complications like hypertensive disorders and preterm birth are known to be higher with GDM are similar to the non-GDM group suggesting that early diagnosis and prompt treatment and maintaining strict glycemic control by participant may be beneficial. GDM can be managed well on MNT and lifestyle modifications, only few patients required insulin therapy. In spite of appropriate glycemic control, the incidence of macrosomia is found to be high in GDM group. Sudden unexplained stillbirth can occur in spite of strict glycemic control. Neonatal 
complications have occurred despite well glycemic control.

Funding: No funding sources

Conflict of interest: None declared

Ethical approval: Not required

\section{REFERENCES}

1. Braunwald, Kasper, Hauser, Longo, Jamesonet. Powers AC. Diabetes mellitus. Harrison principles of Internal Medicine $17^{\text {th }}$ ed. New York: Mc Graw-Hill. 2005;2:2275.

2. Committee on Obstetric Practice. Committee opinion no. 504: screening and diagnosis of gestational diabetes mellitus. Obstet Gynecol. 2011;118(3):7513.

3. O'Sullivan, Mahan CM. Criteria for oral glucose tolerance test in pregnancy. Diabetes. 1964;13:278.

4. Jovanovic L, Braun CB, Druzin ML and Patterson CM. The management of diabetes and pregnancy. Diabetes management. $1^{\text {st }}$ ed. New York. 1982;2865.

5. Fernando A, Daftary SN, Bhide AG. Diabees in pregnancy. In practical guide to high risk pregnancy and delivery.3rd edition. Noida: Saunders Elsevier. 2008; $17: 440$.

6. Abha S. Screening of diabetes mellitus-Why? When? and How? Obstet Gynecol today. 2009;14:233-4

7. Seshiah V, Balaji V, Balaji MS, Sekar A, Sanjeevi $\mathrm{CB}$, Green A. One step procedure for screening and diagnosis of gestational diabetes mellitus. Diabetes. 2005; $126: 200$

8. Seshiah V, Balaji V, Balaji MS, Paneerselvam A, Arthi T, Thamizharasi M, et al. Prevalence of gestational diabetes mellitus in South India (Tamil Nadu) a community based study. J Assoc Physic Ind. 2008;1(56):329-3.

9. Nilofer AR, Raju VS, Dakshayini BR, Zaki SA. Screening in high-risk group of gestational diabetes mellitus with its maternal and fetal outcomes. Indian J Endocrinol Metab. 2012;16(11):74.

10. Das V, Kamra S, Mishra A, Agarwal A, Agarwal CG. Screening for gestational diabetes and maternal and fetal outcome. J Obstet Gynecol India. 2004;54:449-51.

11. Rajput M, Bairwa M, Rajput R. Prevalence of gestational diabetes mellitus in rural Haryana: A community-based study. Indian J Endocrinol Metabol. 2014;18(3):350.

12. Seshiah V, Balaji V, Balaji MS, Sanjeevi CB, Green A. Gestational diabetes mellitus in India. JAPI. 2004;21;52:707-11.

13. Seshiah V, Das AK, Balaji V, Joshi SR, Parikh MN, Gupta S. Gestational diabetes mellitus-guidelines. JAPI. 2006; 1:54.

14. Bhat M, Ramesha KN, Sarma SP, Sangeetha Menon SC, Kumar G. Determinants of gestational diabetes mellitus: A case control study in a district tertiary care hospital in south India. Int J Diabet Developing Countries. 2010;30(2):91.

15. Wahi P, Dogra V, Jandial K, Bhagat R, Gupta R, Gupta S, Wakhloo A, Singh J. Prevalence of gestational diabetes mellitus (GDM) and its outcomes in Jammu region. J Assoc Physicians India. 2011;59(4):227-30.

16. Joy R, Sivakumar V. A Prospective Study on the Effect of Gestational Diabetes Mellitus on Maternal and Fetal Outcome. International Journal. 2012;3(3):345-51

Cite this article as: Jadhav DS, Wankhede UN. Study of maternal, fetal and neonatal outcomes in patients with gestational diabetes mellitus in a tertiary care hospital. Int J Reprod Contracept Obstet Gynecol 2017;6:3014-20. 